\title{
149. Difference in Response to Uterine Trauma between Androgen. and Estrogen-Sterilized Rats Ovariectomized and Given Injections of Progesterone plus Estradiol
}

\author{
By Yasuhiko OHta and Kiyoshi TakewaKI \\ Endocrinology Laboratory, Biology Department, \\ Kawasaki Medical College, Kurashiki, Okayama 701-01 \\ (Comm. by Sajiro Makino, M. J. A., Oct. 12, 1974)
}

Administration of estrogen by a single or repeated injections during the first few days after birth induces a syndrome of sterility characterized by acyclicity and anovulation in female rats when adult which is superficially indistinguishable from that induced by neonatal administration of androgen. In a previous study (Takewaki and Ohta, 1974), we found that the capacity of the endometrium to proliferate and differentiate into a deciduoma in response to trauma was greatly reduced in testosterone propionate (TP)-sterilized adult rats which was given daily injections of an appropriate combination of progesterone (P) and estradiol-17 $\beta$ (ED) following ovariectomy as compared with that in non-androgenized ovariectomized females receiving similar injections.

In experiments incorporated within the present paper, female rats were made anovulatory and persistent-estrous by injecting estrone (EN) neonatally. The rats were ovariectomized when adult and given daily injections of $\mathrm{P}$ plus ED as were the TP-sterilized rats reported previously (Takewaki and Ohta, 1974). It was found that the pattern of uterine response to traumatic stimuli in these animals was considerably different from that in the TP-sterilized rats.

Materials and methods. Nineteen female rats of the $\mathrm{T}$ strain from the colony maintained in this laboratory were given subcutaneous injections of $12.5 \mu \mathrm{g} \mathrm{EN}$ in $0.02 \mathrm{ml}$ sesame oil for the first 5 days of postnatal life. When the animals were 50 days old, daily vaginal smears were examined for at least 10 days to confirm continued vaginal cornification. They were then ovariectomized under ether anesthesia and divided into 2 groups of 10 and 9 animals, respectively. Group I rats received subcutaneous injections of $2 \mathrm{mg} P$ plus $0.2 \mu \mathrm{g}$ ED and Group II animals, $5 \mathrm{mg} \mathrm{P}$ plus $0.2 \mu \mathrm{g} \mathrm{ED}$, for 7 consecutive days commencing on the day following ovariectomy. The daily doses were dissolved in $0.15 \mathrm{ml}$ sesame oil. On the 4 th day of the injection 
period, the luminal surface of endometrium of the right uterine horn was scratched along the entire length with a needle inserted into its lumen (Takewaki, 1969). The traumatic stimuli were applied under ether anesthesia.

On the day after the last injection, the rats were sacrificed. Body weights were determined. After the uteri were grossly examined for deciduomata, traumatized and contralateral intact horns were trimmed of extraneous tissues, weighed separately and fixed in Bouin's solution for histologic study.

The data from the normal control females (Groups V and VI) and the rats sterilized by a single injection of TP given 4 days after birth (Groups III and IV) are reproduced in Table I from the previous paper (Takewaki and Ohta, 1974). These rats were also ovariectomized (the controls were operated at estrus), given 7 daily injections of $2 \mathrm{mg} \mathrm{P}$ plus $0.2 \mu \mathrm{g}$ ED (Groups III and V) or $5 \mathrm{mg} \mathrm{P}$ plus $0.2 \mu \mathrm{g}$ ED (Groups IV and VI) and subjected to uterine traumatization on the 4th day of injection.

All the animals were housed in an air-conditioned room with the light schedule of $14 \mathrm{hr}$ light and $10 \mathrm{hr}$ darkness and allowed to take food and water ad libitum. Data were analyzed using the Student's $t$-test. A probability of 0.01 or less was considered as significant.

Results and discussion. The EN-sterilized rats invariably showed continued vaginal cornification until ovariectomy. In 18 of the 19 rats, the ovaries contained many follicles but no corpora lutea, the mean weight being $35.8 \pm 1.48 \mathrm{mg}$. The ovaries of the one rat having some corpora lutea weighed $71 \mathrm{mg}$. The mean weight of the ovaries bearing no corpora lutea of the $34 \mathrm{TP}$-sterilized rats dealt with in the previous paper was $38.5 \pm 1.43 \mathrm{mg}$. The difference in weight of the polyfollicular ovaries between the two types of sterilized rats is not significant $(\mathrm{P}>0.1)$.

After ovariectomy, vaginal smears from the EN-sterilized as well as the TP-sterilized rats continued to be of the diestrous type during the whole period of P-ED administration, although in some animals cornified cells were predominant in vaginal smears taken on the first day of the period just before the injection. Toward the end of the injection period, copious mucus sometimes appeared in smears. Vaginal smear records from the control rats ovariectomized during vaginal estrus were approximately similar to those from the ovariectomized steroid-sterilized rat. However, smears taken on the first postoperative day rarely contained cornified cells in the control animals.

Thus, the EN-sterilized rats were not distinguishable from the 
Table I. Deciduoma formation in response to uterine trauma in steroid-sterilized and control rats

\begin{tabular}{ccccc}
\hline \multirow{2}{*}{ Group } & $\begin{array}{c}\text { Final body } \\
\text { weight (g) }\end{array}$ & $\begin{array}{c}\text { Positive } \\
\text { response }\end{array}$ & \multicolumn{2}{c}{ Weight (M. \pm S.E. mg) of } \\
\cline { 4 - 5 } & & & & \\
traumatized horn & intact horn \\
\hline EN-sterilized & & & & \\
I & $185.3 \pm 5.5$ & $5 / 10$ & $\begin{array}{c}131.2 \pm 8.5 \\
(110.6 \pm 11.6)^{*}\end{array}$ & $78.6 \pm 4.5$ \\
II & $197.3 \pm 3.7$ & $9 / 9$ & $224.4 \pm 53.8$ & $69.6 \pm 5.5$ \\
\hline TP-sterilized & & & & \\
III & $224.5 \pm 6.0$ & $0 / 10$ & $(132.5 \pm 8.2)$ & $103.2 \pm 4.3$ \\
IV & $199.8 \pm 8.0$ & $5 / 8$ & $224.8 \pm 41.8$ & $118.0 \pm 13.4$ \\
\hline Control & & & & \\
V & $221.1 \pm 7.1$ & $9 / 9$ & $490.0 \pm 47.6$ & $134.1 \pm 7.8$ \\
VI & $212.4 \pm 2.8$ & $10 / 10$ & $735.8 \pm 68.0$ & $137.5 \pm 9.0 *$ \\
\hline
\end{tabular}

EN estrone; TP testosterone propionate.

Groups I, III and V were given injections of $2 \mathrm{mg}$ progesterone plus $0.2 \mu \mathrm{g}$ estradiol for 7 days, while Groups II, IV and VI received injections of $5 \mathrm{mg}$ progesterone plus $0.2 \mu \mathrm{g}$ estradiol for 7 days.

* Mean weights of traumatized horns without deciduomata are given in parentheses.

** Two intact horns which formed deciduomata are not included in this mean.

TP-sterilized females in both ovarian structure and vaginal smear pattern. However, as shown in Table I, the uterine responses to traumatic stimuli were considerably different between these animals. In TP-sterilized rats given daily injections of $2 \mathrm{mg} \mathrm{P}$ together with $0.2 \mu \mathrm{g}$ ED following ovariectomy, uterine traumatization invariably failed to induce a positive response (Group III). By contrast, 5 of the $10 \mathrm{EN}$-sterilized rats similarly treated reacted to uterine trauma by formation of deciduomata (Group I).

The deciduomata produced by the EN-sterilized rats (Group I) were mostly small nodular and in 2 animals microscopical, although unmistakable (Fig. 1), so that the mean weight of the uterine horns showing a positive response of the 5 rats was not significantly different from that of the traumatized horns with no evidence of deciduoma formation of the TP-sterilized rats similarly treated (Group III). It should be noted that the intact horns were smaller in Group I rats than in Group III animals $(\mathrm{P}<0.01)$, indicating that the uteri of the EN-sterilized rats were less strongly stimulated by daily injections of $2 \mathrm{mg} \mathrm{P}$ plus $0.2 \mu \mathrm{g}$ ED as compared with those of the TPsterilized rats. These findings appear to suggest a qualitative difference in uterine responsiveness to trauma between the two groups of sterilized rats. 


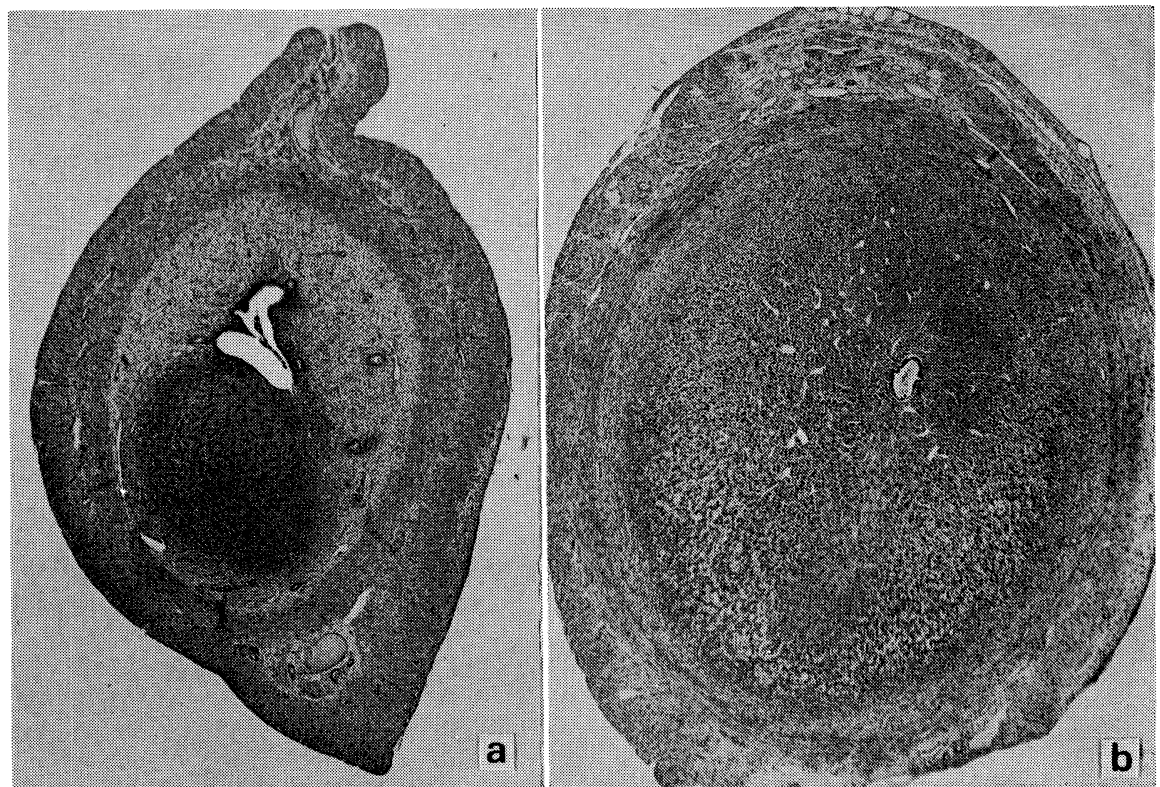

Fig. 1. (a) Small nodular deciduoma and (b) typical deciduoma induced in EN-sterilized rats. $\times 26$

When the daily dose of $\mathrm{P}$ was increased to $5 \mathrm{mg}$ (plus $0.2 \mu \mathrm{g} \mathrm{ED)}$ ), there was no significant difference in mean weight of the traumatized horns bearing deciduomata between the EN-sterilized (Group II) and TP-sterilized animals (Group IV). However, the incidence of deciduomata was again higher in the former $(9 / 9)$ than in the latter $(5 / 8)$. The intact horns were significantly heavier in TP-sterilized rats than in EN-sterilized animals. Since the TP-sterilized and ENsterilized females were similarly anovulatory and persistent-estrous, it appears likely that a difference in direct effect upon the uterus between neonatal administration of TP and EN was largely responsible for the difference in reaction pattern to uterine trauma as adults between the two types of animals, although the continued exposure to endogenous estrogen may have played a part in promoting the difference in uterine responsiveness. McDonald and Doughty (1972, 1974) reported that neonatal injections of $5 \alpha$-dihydrotestosterone exerted a direct action upon the vagina and prevented its opening in female rats.

An impairment of ED binding capacity of the uterus in adult rats treated neonatally with androgen has already been noted (Flerkó and Mess, 1968; Flerkó, Mess and Illei-Donhoffer, 1969; Anderson and Greenwald, 1969; Tuohimaa and Johansson, 1971; Vértes and King, 1971; Maurer and Wooley, 1971, 1974). It is also known that $\mathrm{P}$ binding in the rat uterus is decreased by ovariectomy and can be restored 
to intact levels following estrogen stimulation (Milgrom and Baulieu, 1970 ; McGuire and DeDella, 1971; Feil, Glasser, Toft and O'Malley, 1972). Accordingly, a decrease in ED binding will probably be followed by a reduction of $\mathrm{P}$ binding. A marked decrease in uterine response to trauma in TP-sterilized rats as compared with that in the controls (Table I) may be accounted for by this hypothesis.

ED binding in the uterus of rats treated neonatally with estrogen appears to have received little attention. In mice, Terenius, Myerson and Palis (1969) reported that the uterine ED binding was slightly reduced by neonatal treatment with ED but not with testosterone.

In view of the present findings, it appears likely that neonatal administration of TP and EN may exert different effects on concentrations and/or binding capacities of receptor proteins for ED and $\mathrm{P}$ in the rat uterus.

Summary. Female rats treated neonatally with estrone and testosterone propionate were similarly marked by constant vaginal estrus and sterility due to an absence of ovulation and formation of corpora lutea. When ovariectomized and given daily injections of progesterone and estradiol- $17 \beta$, incidence of deciduomata in traumatized uterine horns was higher in the estrone-sterilized rats than in testosterone propionate-sterilized animals, although the contralateral intact horns were more strongly stimulated in the latter than in the former.

Neonatal injections of estrone appear to have a direct effect upon concentrations and binding capacities of receptors for estrogen and progesterone in the uterus which is different from that exerted by neonatal administration of testosterone propionate.

\section{References}

Anderson, C. H., and G. J. Greenwald (1969): Endocrinology, 85, 1160.

Feil, P. D., S. R. Glasser, D. O. Toft, and B. W. O'Malley (1972) : ibid., 91, 738.

Flerkó, B., and B. Mess (1968) : Acta Physiol. Acad. Sci. Hung., 33, 111.

Flerkó, B., B. Mess, and A. Illei-Donhoffer (1969): Neuroendocrinology, 4, 164.

Maurer, R. A., and D. E. Wooley (1971) : Endocrinology, 88, 1281.

- (1974): Neuroendocrinology, 14, 87.

McDonald, P. G., and C. Doughty (1972): J. Reprod. Fert., 30, 55.

- (1974): J. Endocr., 61, 95.

McGuire, J. L., and C. DeDella (1971) : Endocrinology, 88, 1099.

Milgrom, E., and E.-E. Baulieu (1970) : ibid., 87, 276.

Takewaki, K. (1969) : Annot. Zool. Japon., 42, 126.

Takewaki, K., and Y. Ohta (1974): Endocrinol. Japon., 21 (in press).

Terenius, L., B. J. Meyerson, and A. Palis (1969): Acta Endocr., 62, 671.

Tuohimaa, P., and R. Johansson (1971): Endocrinology, 88, 1159.

Vértes, M., and R. J. B. King (1971): J. Endocr., 51, 271. 